\title{
Medijska pismenost - obrazovanje studenata i svijest o vlastitoj odgovornosti
}

Suzana Peran*

suzanavp@gmail.com

Anđelka Raguž***

araguz@hrstud.hr
UDK: $659.3-057.87$

$378(282+316.77)$

Izvorni znanstveni rad / Original scientific paper Primljeno: 26. rujna 2016. Prihvaćeno: 29. listopada 2016.

U radu propitujemo shvaćanje medijske pismenosti i načine korištenja medija $i$ vrednovanje medijskih sadržaja kod studenata Studija komunikologije Hrvatskih studija i Katoličkoga bogoslovnog fakulteta Sveučilišta u Zagrebu. Pri tome studentima pristupamo kao medijskoj publici, ali i onima koji će u dogledno vrijeme $i$ sami aktivno stvarati medijske sadržaje $i$ znanstveno ih vrednovati te onima koji će poučavati djecu i mlade o medijskim sadržajima. Na temelju provedene ankete analiziramo kolik je stupanj aktivna korištenja medijima $i$ poznavanja osobitosti medijskog funkcioniranja kod studenata komunikologije u okviru svijesti o vlastitoj strukovnoj pismenosti te kolika je svijest o važnosti medijske pismenosti u kontekstu profesionalnoga djelovanja budućih vjeroučiteljica $i$ vjeroučitelja.

U zaključku analiziramo rezultate ankete, te ukazujemo na mogućnost suradnje komunikoloških/novinarskih studija s teološkim i drugim studijima na području medijske pismenosti. Ističemo $i$ važnost poučavanja medijske pismenosti u sklopu obrazovanja medijskih djelatnika i onih koji će aktivno sudjelovati u poučavanju djece i mladih.

Ključne riječi: Medijska pismenost, studenti, Katolički bogoslovni fakultet, Studij komunikologije, demokracija.

\footnotetext{
* Dr. sc. Suzana Peran, Hrvatski studiji Sveučilišta u Zagrebu, Borongajska cesta 83d, HR-10000 Zagreb.

***Anđelka Raguž, mag. nov., Hrvatski studiji Sveučilišta u Zagrebu, Borongajska cesta 83d, HR10000 Zagreb.
} 


\section{Uvod}

U ovome radu pošli smo od stajališta da je medijska pismenost ${ }^{1}$ studenata važna za svijest o njihovoj vlastitoj odgovornosti i društvenom angažmanu ${ }^{2}$ te za jačanje razumijevanja važne uloge medija u demokraciji. Pri tome medijsku pismenost shvaćamo kao mogućnost pristupa medijima, njihova upoznavanja, analiziranja, kritičkog vrednovanja i sposobnost stvaranja medijskog sadržaja. ${ }^{3}$ O odnosu poznavanja funkcioniranja medija - medijske pismenosti - i odgoja mladih za demokraciju intenzivno se počelo pisati još krajem 20. stoljeća. ${ }^{4}$ Kada se govori o važnosti medijske pismenosti u obrazovanju, tada se ističe da medijska pismenost unosi dinamiku u obrazovanje novinara te općenito pomaže studentima da poznavanjem medija i njihovih zakonitosti postanu kritični i svjesni donositelji odluka i aktivni sudionici u društvu. Ona osnažuje pristup studenata informacijama, njihovu analitičnost i komunikacijske vještine; potiče i stvara obrazovno ozračje u kojemu studenti mogu prakticirati vještine slobodnog i odgovornog iznošenja vlastitoga mišljenja te potiče studente da traže pristup različitim izvorima informacija i komunikaciju s različitim idejama i mišljenjima. ${ }^{5}$ Stoga smo u radu pošli od pretpostavke da poznavanje i kritičko vrednovanje medija kod mladih može unaprijediti ne samo kvalitetu medija nego i aktivno sudjelovanje mladih u društvu.

Uočivši da nedostaju istraživanja koja bi propitivala shvaćanja utjecaja medija na kreiranje stavova, načine korištenja medija i vrednovanja medijskih sadržaja, te shvaćanje medijske pismenosti kod studentica i studenata proveli smo istraživanje među studentima Studija komunikologije Hrvatskih studija i Katoličkoga bogoslovnog fakulteta Sveučilišta u Zagrebu. Pri tome smo studentima pristupili kao medijskoj publici, ali i onima koji će u dogledno vrijeme i sami aktivno stvarati medijske sadržaje i znanstveno ih vrednovati te onima koji će poučavati djecu i mlade o medijskim sadržajima. Posebno nas je zani-

${ }^{1}$ U studijama i istraživanjima koja su do sada provedena u Hrvatskoj korišteni su termini medijska pismenost i medijsko obrazovanje, dok u službenim dokumentima dominira termin medijske kulture premda taj termin nije jasno definiran [usp. Igor KANIŽAJ, Viktorija CAR, Hrvatska. Nove prilike za sustavan pristup medijskoj pismenosti, u: V. CAR, L. TURČILO, M. MATOVIĆ (ur.), Medijska pismenost - preduvjet za odgovorne medije, Sarajevo, Fakultet političkih nauka, 2015, 19-38, 26].

2 Hans MARTENS, Renee HOBBS, How media literacy supports civic engagement in a Digital Age, Atlantic Journal of Communication, 23 (2015) 2, 120-137, 122.

${ }^{3}$ Patricia AUFDERHEIDE (ur.), Media Literacy. A report of the national leadership conference on media literacy, Aspen, CO, Aspen Institute, 1993, XX; vidi i u: Patricia AUFDERHEIDE, Media Literacy. From a report of the national leadership conference on media literacy, u: R. KUBEY, Media Literacy in the information age, New Brunswick, NJ, Transaction, 1997, 79-86.

${ }^{4}$ Elihu KATZ, The legitimacy of opposition. On teaching media and democracy, u: B. NEUPARTH (ur.), Media competency as challenge to school and education, Gutersloh, Bertelsmann Foundation Press, 1993, 37.

${ }^{5}$ Renee HOBBS, Building Citizenship Skills through Media Literacy Education, u: M. SALVADOR, P. M. SIAS (ur.), The Public Voice in a Democracy at Risk, Westport, Greenwood Publishing Group, 1998, 62-63. 
mala uloga studentica i studenata u stvaranju vlastite i medijske pismenosti građana te smo željeli ustanoviti kako studenti sami mogu utjecati na kreiranje odgovornije medijske osviještenosti.

Uz studente Studija komunikologije za istraživanje smo i odabrali studente Katoličkoga bogoslovnog fakulteta u Zagrebu jer je riječ o budućim vjeroučiteljima. Prema podacima Nacionalnoga katehetskog ureda Hrvatske biskupske konferencije katolički vjeronauk pohađa između 85 i 90 \% od ukupnog broja učenika u osnovnim školama, te $78 \%$ ukupnog broja učenika u srednjim školama u Republici Hrvatskoj, a u sklopu vjeronauka se na temelju crkvenih dokumenata u više nastavnih cjelina i razreda govori o medijima i njihovu utjecaju na pojedinca i društvo. U drugome razredu srednje škole naglasak je na vrednotama i slobodi izbora, odnosno manipulaciji u medijima; u trećem razredu propituje se odnos prema istini u društvu i u medijima, a u četvrtom razredu govori se o medijima i informiranju - odnosno o medijima u službi istine ili ideologije. ${ }^{6}$ Stoga nas je zanimalo kako medije percipiraju oni koji bi o njima trebali poučavati djecu u sklopu vjeronaučne nastave.

Važno je pri tome istaknuti da i crkveni dokumenti u više navrata govore o odgoju za medije, te ističu da su za njega odgovorni roditelji a za to moraju imati potporu Crkve. ${ }^{7}$ Već dokument Drugoga vatikanskog koncila Intermirifica ${ }^{8}$ upozorava da se vjernike mora poučiti o medijima. Crkva - koja sebe smatra učiteljicom čovječanstva - mora dati svoj prinos za bolje razumijevanje i odgovorno gledanje na medije koje smatra baštinom koju treba čuvati i promicati. ${ }^{9}$ Crkveno djelovanje na području medija prema crkvenim se dokumentima tiče se i formacije - upoznavanje medija i odgoj za odgovorno korištenje, sudjelovanje to jest kulturu suodgovornosti ili dijalog koji mediji mogu promicati na području međusobnoga poznavanja, solidarnosti i mira, kako to navodi dokument Aetatis novae u točci 11. Dokumenti traže da Crkva odgoj za medije provodi u svojim školama i odgojnim programima, ${ }^{10}$ a papa Benedikt XVI. istaknuo je da Crkva želi pružiti roditeljima, učiteljima, medijskim djelatnicima i djeci svoju pomoć u odgoju za medije i njihovo ispravno korištenje. Prema njegovu mišljenju, župe i školski programi trebali bi biti avangarda u odgoju za medije. ${ }^{11}$

\footnotetext{
${ }^{6}$ HBK, Nacionalni katehetski ured, Plan i program katoličkog vjeronauka za četverogodišnje srednje škole, Zagreb, 2009, 3, 24, 41, 49.

${ }^{7}$ IVAN PAVAO II., Familiarisconsortio. Obiteljska zajednica. Apostolska pobudnica o zadaćama kršćanske obitelji u suvremenom svijetu (22.XI.1981), Zagreb, Kršćanska sadašnjost, 2009, br. 76.

${ }^{8}$ DRUGI VATIKANSKI KONCIL, Intermirifica. Dekret o sredstvima društvenog priopćavanja, u: Dokumenti, Zagreb, Kršćanska sadašnjost, 2008, br. 18.

9 Usp. PAPINSKI SAVJET ZA SREDSTVA JAVNOG PRIOPĆIVANJA, Nadolaskom novog doba. Aetatis novae o društvenoj komunikaciji dvadeset godina nakon Communio et progressio, (22.II.1992), Zagreb, Kršćanska sadašnjost, 1992, br. 10 (dalje AN).

${ }^{10}$ PAPINSKO VIJEĆE ZA SREDSTVA DRUŠTVENOG PRIOPĆAVANJA, Communio et progressio. Pastoralni naputak izraden nalogom II. vatikanskog sabora radi primjene Dekreta o sredstvima društvenog priopćivanja istoga Sabora (23.V.1971), Zagreb, Kršćanska sadašnjost, 2002, br. 107 (dalje CP).

${ }^{11}$ BENEDIKT XVI., Poruka za 41. svjetski dan sredstava društvenih komunikacija. Djeca
} 


\section{Empirijsko istraživanje}

U radu želimo usporediti mišljenja i stavova studentica i studenta prve godine preddiplomskog Studija komunikologije na Hrvatskim studijima i prve i druge godine Katoličkoga bogoslovnog fakulteta Sveučilišta u Zagrebu o različitim aspektima utjecaja medija na pojedinca i društvo, razumijevanje načina na koji mediji svakodnevno djeluju te sukladno s time kako studenti sami na dotadašnjoj razini svoga obrazovanja vrednuju medijske sadržaje.

Sukladno tome, svrha istraživanja je na temelju stavova naših ispitanica i ispitanika otkriti kakvo je njihovo dotadašnje medijsko obrazovanje te postoji li bitna razlika između studenata dvaju studija pri zagrebačkom sveučilištu kada je riječ o vlastitoj odgovornosti i društvenu angažiranju studentske populacije za koju se predmnijeva da će u dogledno vrijeme stvarati medijski sadržaj ili predavati učenicima u osnovnim i srednjima školama o istome. U tom smislu, medijima smo pristupali kao posrednicima i stvarateljima utjecaja na stavove i mišljenja ispitanika, a studenticama i studentima kao potencijalnim budućim (su)kreatorima društvene zbilje kroz platformu medijskih sadržaja.

Empirijsko istraživanje provedeno je na prigodnom odnosno raspoloživom uzorku koji je činilo ukupno stotinu studentica i studenata prve i druge godine preddiplomskih studija: Studija komunikologije na Hrvatskim studijima ${ }^{12}$ i Katoličkoga bogoslovnoga fakulteta Sveučilišta u Zagrebu. ${ }^{13}$ Ova tehnika neprobabilističkoga uzorkovanja podrazumijeva obuhvaćanje skupine pojedinaca dostupnih u određenoj prigodi, koji su dio populacije na koje se odnose rezultati istraživanja. ${ }^{14}$ Stoga ćemo $u$ interpretaciji naših rezultata držati odmak od čvrstih zaključaka i generaliziranja na cijelu studentsku populaciju obaju fakulteta i studijskih godina.

Da bi se ispitali stavovi i mišljenje ispitanika i ispitanica za potrebe ovoga istraživanja korištena je metoda ankete. ${ }^{15}$ Istraživanje je obuhvatilo izradu anketnog upitnika i provedbu istraživačke ankete među studentima i studenticama, ${ }^{16}$ te analizu i interpretaciju dobivenih odgovora. Pri interpretaciji i prezentaciji prikupljenih rezultata korištena je metoda deskriptivne statistike.

i komunikacijska sredstva. Izazov za odgoj. (24.01.2007), br. 3; www.ika.hr/index. php?prikaz=vijest\&ID=94330 (24.08.2016).

${ }^{12}$ Anketni je upitnik ispunilo 39 studentica (83 \%) i 8 studenata komunikologije (17 \%).

${ }^{13}$ Anketni je upitnik ispunilo 24 studentice (45 \%) i 29 studenata Katoličkoga bogoslovnog fakulteta (55\%).

${ }^{14}$ Goran MILAS, Istraživačke metode u psihologiji i drugim društvenim znanostima, Jastrebarsko, Naklada Slap, 2009, 406.

${ }^{15}$ Ana TKALAC VERČIĆ, Dubravka SINČIĆ ĆORIĆ, Nina POLOŠKIVOKIĆ, Priručnik za metodologiju istraživačkog rada. Kako osmisliti, provesti $i$ opisati znanstveno i stručno istraživanje, Zagreb, M.E.P., 2010, 103; Vesna LAMZAPOSAVEC, Metode istraživanja u novinarstvu, Zagreb, Fakultet političkih znanosti Sveučilišta u Zagrebu, 2006, 69.

${ }^{16} \mathrm{U}$ nastavku rada: studenti. 
Anketni je upitnik sadržavao ukupno 43 pitanja. Zbog pouzdanosti, ali i ekonomičnosti te brzine provedbe, istraživanje je provedeno anketnom metodom »olovka i papir«. Saznanja o stavovima ispitanika prikupljana su tehnikom otvorenih i zatvorenih pitanja koja su vrednovana Likertovom skalom. U kategoriji pitanja kojima su ispitanici označavali stupanj slaganja s navedenim (predloženim) tvrdnjama o poznavanju medijske kulture i medijske pismenosti, njihova uključivanja u obrazovni sustav te $s$ jedne strane funkcioniranja i strukture medija odnosno procjenjivanja kvalitete medijskog sadržaja, skala je bila postavljena u sljedećim intervalima: (1) uopće se ne slažem - (5) slažem se u potpunosti. Također, upitnik je nudio i dihotomne opcije odgovora (da/ne) s filtar opcijom (ne znam) koje su uglavnom uključivale pitanja u vezi sa svakodnevnim korištenjem medija. Da bismo eksplicitno propitali stavove, mišljenja i očekivanja ispitanika kao i druge pokazatelje (kritičkog) vrednovanja, s jedne strane medija te s druge strane obrazovnog sustava na području uključivanja medijske kulture u sustav visokoobrazovnih ustanova, pred kraj anketnog upitnika postavljali smo i otvorena pitanja. Tim smo pitanjima nastojali osigurati da ispitanici sami ponude uvid u vlastita znanja i stavove te smo tako dopunili i kategoriju ranijih zatvorenih pitanja.

Opći cilj istraživanja bio je istražiti kolik je stupanj aktivnoga korištenja medijima i poznavanja osobitosti medijskog funkcioniranja kod studenata komunikologije u okviru svijesti o vlastitoj strukovnoj pismenosti te koliko koriste medije i kolika je svijest o važnosti medijske pismenosti u kontekstu profesionalnog djelovanja budućih vjeroučitelja. U tom smislu, specifični ciljevi istraživanja su, s obzirom na različite studijske smjerove ispitanika, bili utvrditi i usporediti: shvaćanje utjecaja medija na kreiranje vlastitih stavova; znanja o pojmu i svrsi medijske pismenosti te načine korištenja medija i vrednovanje medijskih sadržaja među ispitanicima iste dobi, ali različitih studijskih usmjerenja.

$\mathrm{Na}$ temelju toga postavljeno je šest istraživačkih pitanja. Zanimalo nas je: koliko studentice i studenti aktivno koriste medije, na koji način im pritom pristupaju kao publika te jesu li svjesni da će vrlo brzo i sami postati kreatori medijskoga sadržaja? Također nas je zanimalo primjećuju li i koje konkretne propuste, odnosno dobre primjere prilikom izvještavanja hrvatskih medija i medijskih djelatnika te, u skladu s time, koliko poznaju osobitosti i uzuse medijske kulture.

Sukladno tome, za potrebe ovoga istraživanja postavljene su tri hipoteze:

1. Studenti najčešće medije koriste da bi se informirali;

2. Studenti komunikologije različito percipiraju važnost medijske pismenosti od studenata Katoličkoga bogoslovnog fakulteta;

3. Studenti smatraju da je stanje u hrvatskom novinarstvu loše.

Studentima smo u našem istraživanju pristupali na četiri razine, a na temelju toga smo interpretirali i dobivene odgovore. Ispitanicima smo pristupali 
kao medijskoj publici. To je ujedno razina koju ostvaruju za vrijeme studija, ${ }^{17} \mathrm{a}$ time svijest o trenutačnoj vlastitoj odgovornosti i društvenu angažiranju može utjecati na njihovo shvaćanje preostalih razina. Nadalje, studentima smo pristupali i kao onima koji će u budućnosti biti kreatori medijskog sadržaja te, nasuprot tome, kao onima koji će poučavati djecu i mlade o medijskim sadržajima i njihovoj kvaliteti. Uloga analitičara medija i znanstvenika koji će vrednovati medijski sadržaj je posljednja od razina koju smo pretpostavili u (su)odnosu ispitanika spram predmeta istraživanja. Premda nam je anketno istraživanje pružilo značajne podatke, ne samo o studentskim stavovima i znanjima već ponajprije o činjenici kako oni sami prepoznaju nedostatke u obrazovnom kurikulumu te predlažu uvrštenje predmeta o medijskoj kulturi i pismenosti u redovito školovanje, svjesni smo metodoloških ograničenja pri provedbi ovakva oblika istraživanja. Naime, odabirom uzorka, nismo bile ograničeni samo na odabrane pojedince studentske populacije već na one među njima, za koje pretpostavljamo da su zainteresirani za sadržaj kolegija u sklopu kojih smo istraživanje i proveli.

Premda su studentima i studenticama s oba studijska usmjerenja postavljena identična anketna pitanja, u nastavku rada te prilikom obrade podataka i interpretacije rezultata, napravljena je razlika, odnosno pitanja i dobiveni odgovori razvrstani su spram specifičnih kategorija: (1) korištenje i uloge medija u životu studenata; (2) znanja o (vlastitom) medijskom obrazovanju te (3) povjerenje u medije i vjerodostojnost hrvatskih medija, a posljedično i (4) svijest o nužnosti vlastitoga društvenoga doprinosa. Ovo istraživanje smatramo zapravo polaznim za daljnja slična istraživanja, a držimo da bi ga bilo korisno i ponoviti među studentima završnih godina istih studija.

\section{Rezultati istraživanja i rasprava}

\subsection{Korištenje i uloga medija u svakodnevnom životu studenata}

Jedan od specifičnih ciljeva istraživanja bio je usporediti korištenje i ulogu medija u svakodnevnom životu studenata Studija komunikologije i Katoličkoga bogoslovnog fakulteta Sveučilišta u Zagrebu. Naše je istraživanje pokazalo da studenti komunikologije medije dnevno koriste u prosjeku oko 10 sati, a studenti KBF-a tri sata. ${ }^{18}$ Rezultati pokazuju da većina ispitanih studenata (62

\footnotetext{
${ }^{17} \mathrm{Na}$ kasnijim godinama studija studenti komunikologije u okviru obvezne prakse i vlastitog angažmana u studentskim i drugim medijima i sami proizvode medijske sadržaje.

${ }^{18}$ Prema istraživanju hrvatski građani u korištenju medija dnevno koriste Internet 6,89 sati, radio 2,81 , televizijski program gledaju 2,58 sati, novine čitaju 0,67, a časopise 0,61 sati. Najviše se internet koristi dnevno 1-2 sata (17,86 \% ispitanih), dok ga 10 i više sati koristi 6,10 \% ispitanih [usp: Istraživanje o medijskim navikama hrvatskih građana - Iab-Croatia: CroMedia-
} 
\% studenata KBF-a i 81 \% studenata komunikologije), medije svakodnevno koristi radi informiranja o novostima iz zemlje i svijeta, što je i potvrdilo našu prvu početnu pretpostavku. Od studenata komunikologije $84 \%$, a od studenata KBF-a 63 \% izjavilo je da se medijima svakodnevno koriste za informiranje, zabavu i kontakt s prijateljima i obitelji. Takvi rezultati, mogli bismo zaključiti, potvrđuju da i studenti sami prepoznaju primarnu ulogu medija ${ }^{19}$ te da im mediji služe i za socijalizaciju. Tako su studenti (komunikologije - 55 \% i KBFa $-34 \%$ u većini slučajeva uvjereni da je značajna uloga medija pomaganje pri upoznavanju različitih skupina u društvu. Dobiveni podaci pokazali su i da $2 \%$ ispitanih studenta komunikologije, odnosno $8 \%$ studenata Katoličkoga bogoslovnog fakulteta ne koriste društvene mreže odnosno ne participiraju na internetskim društvenim platformama. Među društvenim mrežama ispitani studenti najviše koriste Facebook (94\% ispitanih studenata komunikologije i $87 \%$ studenata teologije), zatim Instagram ( $34 \%$ studenata komunikologije i 26 \% studenata teologije), a najmanje Twitter (13\% studenata komunikologije i 9 \% studenata teologije). I inače među hrvatskim studentima Facebook još uvijek drži prvo mjesto, dok je broj korisnika te mreže u svijetu u populaciji od 16 do 24 godine u opadanju i iznosi $25 \%$ ukupnih korisnika. ${ }^{20}$ Također nam se čini važnim u nekom sljedećem istraživanju istražiti koliko studenti teologije prate objave službenih crkvenih ustanova na društvenim mrežama.

Osim za informiranje i za zabavu, 61 \% ispitanih studenata komunikologije i 58 \% studenata KBF-a medije koriste za pomoć u učenju. Taj podatak govori $\mathrm{u}$ korist $»$ nove kulture učenja ${ }^{21}{ }^{21} \mathrm{u}$ kojoj se, posebno, digitalni mediji koriste $\mathrm{u}$ obrazovne svrhe, odnosno za usvajanje nastavnih sadržaja. Ispitani studenti s obaju fakulteta u podjednakom postotku ističu da se osjećaju osposobljenima za ispravno i učinkovito korištenje medija (66 \% studenata komunikologije i $64 \%$ studenata KBF-a), dok istodobno 75 \% studenata komunikologije i $53 \%$ studenata KBF smatra da poznaje tehnologije i medijske alate novih medija. U potpunosti se dobrim komunikatorima osjeća $17 \%$ ispitanih studenata komunikologije i $30 \%$ studenata teologije.

Prilikom ispitivanja navika korištenja medija željeli smo saznati koliko su ispitanici svjesni medijskog utjecaja na njihove stavove i odluke te postoji li, prema njima, recipročna veza u pogledu vlastite odgovornosti s obzirom na prihvaćanje, odnosno odbijanje medijskog sadržaja. Odgovornima u korištenju medija smatralo se 51 \% ispitanih studenata komunikologije i 75 \% studenata

scope 2015., http://ftpaccess.fuzzyeye.org/Jan/IAB_CROmediascope_2016_17_02_1DIO.pdf (02.09.2016)].

${ }^{19}$ Usp. Zlatko MILIŠA, Uloga medija u razvoju interkulturalne komunikacije, Pedagogijska istraživanja, 5 (2008) 1, 219-231, 220-221.

${ }^{20}$ Koje su trenutno najpopularnije društvene mreže? Istraživanje Global Web Indexa za 2015. godinu, www.inpublic.hr/facebook-instagram-snapchat-koje-su-trenutno-najpopularnijedrustvene-mreze (04.09.2016).

${ }^{21}$ Stjepan RODEK, Novi mediji i nova kultura učenja, Napredak, 152 (2011) 1, 9-28. 
teologije. Na pitanje promiču li mediji vrijednosti u društvu, ispitani studenti KBF-a odgovorili su podjednako da promiču i ne promiču ( $40 \%$ promiču, 41 $\%$ ne promiču), dok je $43 \%$ studenata komunikologije odgovorilo potvrdno. Pri tome je zanimljivo istaknuti da čak $40 \%$ studenata komunikologije nema stav prema tome pitanju.

Značajan raskorak $\mathrm{u}$ odgovorima studenata pokazao se $\mathrm{u}$ odgovoru na pitanje utječu li mediji na vaše stavove i uvjerenja. Mediji tako utječu na 51 $\%$ ispitanih studenata komunikologije i na $17 \%$ studenata teologije (66 \% ih smatra da ne utječu). Istodobno $13 \%$ komunikologa i $17 \%$ teologa ne zna utječu li mediji na kreiranje njihovih stavova i uvjerenja. Ti su odgovori indikativni u surječju činjenice da upravo studenti komunikologije više uče o mogućim opasnostima i negativnim stranama utjecaja medija te psihologiji medijskih učinaka na publiku. Odgovor na to pitanje može se povezati i s odgovorima iz ranijih istraživanja koja su pokazala da se, budući da se o utjecaju medija govori u negativnom kontekstu, smatra da mediji mogu utjecati na druge te posebno na one manje obrazovane. ${ }^{22}$ Možemo istaknuti da je očita razlika $u$ mišljenju uočena i kod tvrdnje kojom se isticalo da je u suvremenim medijskim uvjetima važna uloga publike u stvaranju medijskih sadržaja. Naime, gotovo je 66 \% budućih komunikologa svjesno mogućnosti i važnosti obrnutog utjecaja (publika↔mediji) na nastanak i objavu medijskog sadržaja, dok je manje od polovine ispitanih - 24 studenata KBF-a - uvjereno u takvu mogućnost.

Stoga smo otvorenim pitanjima željele »isprovocirati« njihova razmišljanja o odgovornosti za medijski sadržaj. S obzirom na odgovore na otvorena pitanja naših ispitanika zaključujemo da dominira ideja podijeljene odgovornosti.

Navodimo dva reprezentativna odgovora:

- Podijeljena je odgovornost te nije odgovornost samo na novinarima, već $i$ na vlasnicima medija. Na temelju dosadašnjih iskustava je vidljivo da su medijski sadržaji kontinuirano izvrgnuti ideologijama, ali su paralelno često prikrivene u medijima.

- Ono što bi definitivno trebalo povećati jest izobrazbu novinara o odgovornosti. Što sam $i$ sam sve više u medijskom okruženju, shvaćam da sve manje znam.

Iz toga se može zaključiti da ispitanici u svojim razmišljanjima ne stavljaju odgovornost za medijski sadržaj samo na jednu stranu već su svjesni različitih razina odgovornosti. Takvi odgovori ne iznenađuju jer je riječ o studentima Studija komunikologije na kojemu studenti uče o funkcioniranju medija i nastanku medijskih sadržaja, a crkveni dokumenti, koje izučavaju studenti teologije, govore o odgovornosti svih sudionika medijskog komuniciranja.

\footnotetext{
${ }^{22}$ Suzana PERAN, Slika obitelji u hrvatskim medijima, neobjavljena doktorska disertacija, Zagreb, 2012, 97.
} 


\subsection{Medijsko obrazovanje (znanje) studenata}

U istraživanju smo željeli povezati korištenje medija, medijsko obrazovanje sa znanjima i promišljanjima vezanim uz poimanje društvene odgovornosti i angažmana kod studenata koji o učincima medijskih sadržaja već imaju neka (pred)znanja. Rezultati istraživanja pokazuju da su studenti svjesni nedostataka i manjkavosti u dosadašnjem obrazovnom sistemu kada se govori o medijskoj pismenosti. Naime, svega četvero od ukupnog broja ispitanih sa studija KBFa smatra da je medijska kultura ${ }^{23} u$ dovoljnoj mjeri zastupljena u hrvatskom obrazovnom sustavu, ${ }^{24}$ odnosno samo jedan ispitanik više sa Studija komunikologije razmišlja na isti način. Nadalje, 44 \% budućih komunikologa, odnosno 37 \% njihovih kolega s drugog fakulteta smatra da je važno da se o medijskoj kulturi uči i tijekom osnovnog, odnosno srednjoškolskog obrazovanja ${ }^{25}$ (samo je jedan ispitanik s KBF-a uvjeren da ga je prethodno obrazovanje pripremilo na razumijevanje medijskih sadržaja) te je prema njihovu mišljenju u tom smislu važnije praktično učenje o medijima. ${ }^{26}$ Osim toga, važno nam se čini naglasiti da su budući komunikolozi u otvorenim pitanjima češće eksplicitno isticali potrebu da se o medijskoj kulturi uči još i prije redovnog školovanja, i to u vrtićima, na radionicama, ali također da takvo učenje treba postati obvezno i na razini svih sveučilišnih studija. Takvi se odgovori mogu protumačiti i činjenicom da su neki profesori i studenti toga fakulteta aktivno uključeni $u$ medijsko opismenjivanje mladih kroz projekt Djeca medija, ${ }^{27}$ ali i Komunikološku školu Matice hrvatske. ${ }^{28}$ Treba pritom naglasiti da se 47 \% budućih komunikologa, nasuprot $17 \%$ ispitanika s drugog fakulteta, u trenutačnoj fazi svoga obrazovanja smatra osposobljenima za ispravno korištenje medijima. Manjem postotku u prilog zasigurno ide činjenica što čak $66 \%$ potonjih studenata nije, odnosno njih $11 \%$ ne zna jesu li, do sada slušalo kolegij koji se među ostalim bavio i medijskom kulturom, odnosno medijskom pismenošću.

Naposljetku, prioriteti medijskog obrazovanja prema našim ispitanicima s oba studija su: sigurno korištenje medijima, medijska pismenost, razvoj komunika-

\footnotetext{
${ }^{23}$ Neki od odgovora na pitanje »Što je medijska kultura?«: obrazovanje o medijima; odgovorno korištenje medijima i kritično poimanje prema medijskim objavama; medijska kultura bi trebala biti u službi izgradnje čitave društvene zajednice u kulturnom, moralnom i društvenom smislu za dobrobit informiranja i upućivanja javnosti, bilo pojedinca ili veće skupine ljudi, a ne isključivo u korist i za interes svoga poslodavca; odnosi se na svojevrsnu medijsku pismenost koja se očituje u korištenju medijskih sadržaja na relevantan $i$ ispravan način.

${ }^{24} \mathrm{U}$ trenutku provođenja istraživanja.

${ }^{25}$ Studenti KBF-a: uvođenje u osnovne škole (25 ispitanika), odnosno u srednje škole i gimnazije (31 ispitanik); studenti komunikologije: u osnovne škole (20 ispitanika), odnosno u srednje škole i gimnazije (29 ispitanika).

${ }^{26} 48$ \% studenata komunikologije i $38 \%$ studenata KBF-a.

${ }^{27}$ Usp. Danijel LABAŠ, Djeca medija - mladi obrazuju mlade, u: V. CAR, L. TURČILO, M. MATOVIĆ (ur.), Medijska pismenost - preduvjet za odgovorne medije, Sarajevo, Fakultet političkih nauka, 2015, 105-117.

${ }^{28}$ Više o tome na: www.matica.hr/komunikoloska.skola/ (12.09.2016).
} 
cijskih vještina i sposobnost kritičkog prosuđivanja, osposobljavanje učenika za odgovorno i kritičko korištenje medijima te razvijanje medijske kulture u širem smislu. S jedne strane, studenti s KBF-a svoje prioritete usklađuju sa studijskim pristupom te navode i razvijanje objektivnih stavova i kulture dijaloga, prenošenje istine i obrazovanja mlađih generacija o virtualnom dostojanstvu svake osobe i pravo svakoga na točnu informaciju, o čemu govore i crkveni dokumenti o medijima. S druge strane budući komunikolozi navode kritički pristup spram objavljenoga medijskog sadržaja te sigurnost pri korištenju medijima, napose u suvremenom kontekstu digitalnih medija i društvenih mreža koji svim korisnicima dopuštaju da objavljuju »vijesti«. To znači, prema našim ispitanicima, i da bi u predmet o medijskoj kulturi trebale biti uključene teme o teorijskim polazištima medijske pismenosti, teme o stjecanju praktične kompetencije, posebno na području društvenih mreža i digitalnih medija, povijesti medija, kulturi govorenja i javnoga nastupa, medijskoj etici te o odnosu religije i medija.

Tablica: Pristup, znanje i prijedlozi ispitanika prema uključenju medijske kulture u obrazovni sustav

\begin{tabular}{|c|c|c|c|}
\hline & PRISTUP & ZNANJE & PRIJEDLOZI \\
\hline $\begin{array}{l}\text { Komuni- } \\
\text { kologija }\end{array}$ & $\begin{array}{l}\text { Znanstveno- } \\
\text { fokusiran }\end{array}$ & $\begin{array}{l}\text { Konkretno } \rightarrow \text { u kontekstu } \\
\text { rekonstrukcija dosad stečenog } \\
\text { (znanstvenog) znanja. } \\
60 \% \text { studenata medijski pismeno; } \\
63 \% \text { studenata zna što je medijska } \\
\text { pismenost; } \\
46 \% \text { studenata misli da zna kreirati } \\
\text { medijsku poruku; } \\
56 \% \text { studenata se uglavnom slaže } \\
\text { da imaju znanja u razumijevanju } \\
\text { medijskih poruka. }\end{array}$ & $\begin{array}{l}\text { Zainteresirani } \\
\text { za medijsko } \\
\text { obrazovanje } \\
\text { i mijenjanje } \\
\text { pristupa } \\
\text { u korist } \\
\text { uključenja } \\
\text { medijske } \\
\text { kulture u } \\
\text { obrazovni } \\
\text { sustav. }\end{array}$ \\
\hline $\begin{array}{l}\text { Katolički } \\
\text { bogoslovni } \\
\text { fakultet }\end{array}$ & $\begin{array}{l}\text { Problemski } \\
\text { orijentiran; } \\
\text { društvena re } \\
\text { konstrukcija } \\
\text { znanstvenog } \\
\text { "problem« } \rightarrow \\
\text { definira se u } \\
\text { odnosu prema } \\
\text { društvenim } \\
\text { problemima; }\end{array}$ & $\begin{array}{l}\text { Apstraktno } \rightarrow \text { specijalističko } \\
\text { široka perspektiva } \\
\text { opći pregled i iskustvo } \\
\text { razni aspekti } \\
\text { inter/pluri-perspektivno. } \\
39 \% \text { studenata medijski pismeno; } \\
36 \% \text { studenata zna što je medijska } \\
\text { pismenost; } \\
21 \% \text { studenata misli da zna kreirati } \\
\text { medijsku poruku; } \\
36 \% \text { studenata se uglavnom slaže } \\
\text { da imaju znanja u razumijevanju } \\
\text { medijskih poruka. }\end{array}$ & $\begin{array}{l}\text { Medijsko } \\
\text { obrazovanje } \\
\text { povezati sa } \\
\text { sociološkim, } \\
\text { filozofskim } \\
\text { i teološkim } \\
\text { učenjima. }\end{array}$ \\
\hline
\end{tabular}

$\mathrm{N}=39$ studentica i 8 studenata komunikologije; N = 24 studentice i 29 studenata Katoličkoga bogoslovnog fakulteta 


\subsection{Povjerenje u medije i svijest o vlastitom društvenu angažmanu}

S obzirom na medijsku prožetost društva bilo je razumljivo $u$ istraživanje uključiti i pitanja o povjerenju u medije, odnosno poimanju društvene odgovornosti studenata kao primatelja, ali i budućih kreatora medijskih sadržaja. Stoga smo postavili pitanje s unaprijed danom, pomalo i sugestivnom, pretpostavkom da studenti tih fakulteta ${ }^{29}$ moraju biti više društveno angažirani od ostalih kolega s drugih fakultetskih usmjerenja. 8 \% studenata KBF-a s time se uglavnom ne slaže, nasuprot $45 \%$ njihovih kolega s iste godine studija koji se s tezom pojačanoga društvenog angažmana u potpunosti slažu. Razmišljanja budućih komunikologa o istome, a u vezi s njihovim studijem, pokazuju nešto slabiju razinu svijesti o potrebi društvene participacije. Naime, svega 38 \% ispitanika smatra da ih buduće zanimanje i trenutačni akademski stupanj obvezuju na društveni angažman, odnosno $15 \%$ njih je indiferentno spram toga. Osobito je takav pristup vidljiv kod danih primjera: $83 \%$ studenata komunikologije, koji već u sklopu studijskoga programa analiziraju medijski sadržaj te koji se uvelike osposobljavaju za kreiranje medijskih poruka, nikada nije reagiralo na objavljeni medijski sadržaj, pismom ili pozivom uredništvu, ali je njih $66 \%$ pritom svjesno da čitatelji, slušatelji odnosno gledatelji, mogu utjecati na medije i njihove objave. Studenti bi možda reagirali, kako su sami naveli, kada je riječ o medijskom sadržaju koji uključuje netočne, neetične ili uvredljive informacije te sadržaj kojim je otkriven identitet djece i/ili odraslih. Za razliku od komunikologa, 32 \% studenata KBF-a odgovorilo je da su reagirali na sadržaj koji je objavljen u medijima, premda ih je nešto više od $35 \%$ uvjereno da u hrvatskom medijskom prostoru publika ne može utjecati na sadržaj koji se objavljuje u medijima. Takvi odgovori pokazuju da studenti teologije, premda nemaju potrebna znanja o medijima, osjećaju da im je društvena odgovornost reagirati na sadržaje koje ne smatraju kvalitetnima ili primjerenima.

Društveni angažman studenata može se povezati i s povjerenjem u medije općenito i s njihovom procjenom objektivnosti medijskoga izvještavanja. Naše je istraživanje pokazalo da čak $54 \%$ ispitanih studenata komunikologije nema jasno izražen stav o povjerenju u medije, a medijima vjeruje samo $4 \%$ studenata toga fakulteta. Medijima i medijskom sadržaju uglavnom, te u istom omjeru i u potpunosti, ne vjeruje $34 \%$ studenata KBF-a (ukupno $64 \%$ ). Ti su brojčani pokazatelji, mogli bismo zaključiti, nastavak dugogodišnjega društvenog trenda. Naime, slično su pokazala i druga istraživanja u kojima su hrvatski građani pokazali nisku razinu povjerenja prema medijima, osobito prema televiziji (16,3 $\%)$ i tisku (22,5 \%). ${ }^{30}$ Gotovo su istovjetni rezultati potvrđeni i u istraživanju iz

\footnotetext{
${ }^{29}$ Studenti komunikologije moraju biti više društveno angažirani od ostalih studenata; studenti KBF-a moraju biti više društveno angažirani od ostalih studenata.

${ }^{30}$ Mirko MATAUŠIĆ, Gordan ČRPIĆ, Povjerenje u medije, Bogoslovska smotra, 68 (1998) 4, 673 683.
} 
2012., kada je u Hrvatskoj samo 21 \% građana vjerovalo medijima, ${ }^{31}$ a prema istraživanju Antonije Čuvalo iz 2010. godine, hrvatsko je društvo više vjerovalo Crkvi nego medijima. ${ }^{32}$

$\mathrm{S}$ time u vezi zanimalo nas je kako studenti-ispitanici percipiraju, točnije što predmnijevaju pod pojmom medijske objektivnosti, a posljedično i kako ocjenjuju medijska izvještavanja.

Navodimo neke od reprezentativnih odgovora studenata:

- Medijska je objektivnost sinonim za nepristrano izvještavanje.

- Objektivnost bi se trebala temeljiti na nepristranosti, bez obzira na aktere i temu.

- U Hrvatskoj je medijska objektivnost stran pojam.

- Novinari bi trebali izvijestiti onako kako jest i prihvatiti različitosti (primjer je referendum o braku, kada se uvidjela razjedinjenost naroda).

- Objektivno je izvještavanje lišeno manipulacija.

- Podudaranje medijskih informacija $i$ stvarnosti je objektivan $i$ odgovoran pristup.

- Oslobođenost od ideološke ili osobne komponente pri prenošenju informacija.

- Sposobnost da se bude neutralan u izvještavanju koje ima emocionalne konotacije.

Dobiveni odgovori pokazuju da studenti kao korisnici medija većinom nemaju povjerenja u medije, kritični su prema medijskom izvještavanju, no ne reagiraju na propuste nego se kritika medija zaustavlja na razini sudjelovanja u raspravama s kolegama i nastavnicima. I iz tih se odgovora vidi važnost medijskoga opismenjavanja mladih kojoj je cilj osposobiti mlade da razumiju i kritički vrednuju medijski sadržaj i zatim djeluju da ne bi ostali pasivni primatelji medijske poruke bez svijesti o vlastitoj odgovornosti.

\subsection{Kritičke kompetencije studenata prilikom vrednovanja kvalitete medijskog sadržaja}

U istraživanju nas je zanimalo i kako studenti vrednuju hrvatske medije i sadržaje koje ti mediji objavljuju. Rezultati pokazuju da se svega četvero od ukupnog broja ispitanih (po dvoje sa svakog fakulteta) u potpunosti slažu s

\footnotetext{
${ }^{31}$ Igor KANIŽAJ, Zašto građani ne vjeruju medijima?, www.matica.hr/vijenac/495/ Za\%C5\%A1to\%20gra\%C4\%91ani\%20ne\%20vjeruju\%20medijima\%3F/ (10.09.2016).

${ }^{32}$ Antonija ČUVALO, Osobine medijskih publika i povjerenje u medije, Medijske studije, 1 (2010) $1-2,40-54$.
} 
tezom da su hrvatski mediji pouzdan izvor informacija, a istodobno 23 studenata komunikologije i 13 s KBF-a se s istim uglavnom ne slažu. Također, studenti uopćeno više iskazuju nezadovoljstvo prema vjerodostojnosti medija. No, pritom je ponovno uočljiva veća kritičnost studenata Katoličkoga bogoslovnog fakulteta. Naime, njih je 75 \%, nasuprot 60 \% budućih komunikologa iskazalo kritičnost spram vjerodostojnosti hrvatskih medija. Kritičnost budućih teologa i vjeroučitelja prema medijima može se povezati i s odgovorom o promicanju vrijednosti, gdje se većina izjasnila da mediji ne promiču vrijednosti u društvu.

Na pitanje: »Što je prema Vašem mišljenju kvalitetan medijski sadržaj?«, studenti su u odgovorimakvalitetu i vjerodostojnost poistovjećivali s istinitošću:

- Onaj koji je istinit, poučan, a u isto vrijeme zabavan.

- Istinit i zanimljiv.

- Istinit i točan.

- Istinit i provjeren.

- Onaj koji prenosi vjerodostojne informacije.

- Onaj koji je istinit i potpun.

- Istinit sadržaj koji je odraz stvarnosti.

- Objektivan, poticajan i poučan.

- Onaj koji promiče istinu i istinske vrijednosti.

- Onaj koji promiče općeljudske (kršćanske) vrijednosti.

Najveći propusti hrvatskih medija, prema odgovorima naših ispitanika, su: neobjektivnost, subjektivnost, priklanjanje stanovitoj ideologiji i stranci, odmak od vjerodostojnosti, korištenje neprovjerenih informacija, pristranost, manjak pismenosti, previše senzacionalističkog pristupa.

Navedeni odgovori potvrđuju našu hipotezu da studentice i studenti stanje u hrvatskom novinarstvu procjenjuju izuzetno lošim.

Premda su, s jedne strane, studenti više pokazali spremnost na kritički pristup, s druge strane pokazali su ravnodušnost prema prepoznavanju istraživačkog, odnosno analitičkog novinarstva u Hrvatskoj. Na tvrdnju u anketi da u Hrvatskoj postoji istraživačko novinarstvo, 53 \% studenata komunikologije, odnosno 47 \% KBF-a odgovorilo je da se s time niti slažu niti ne slažu. Takav odgovor pokazatelj je, s jedne strane, možebitnog neznanja, dok je s druge strane naznaka nezainteresiranosti koja je u skladu i s prije prikazanom slabom društvenom aktivnošću. Ako bismo to povezali s odgovornošću prema korištenju medijima, ${ }^{33}$ onda je zasigurno potvrđeno da ih medijski propusti koje uočavaju

${ }^{33} 75$ \% studenta KBF-a i $51 \%$ studenata komunikologije smatra se odgovornima pri korištenju medijima. 
ne potiču na slobodno i odgovorno iznošenje vlastitoga mišljenja, odnosno na aktivnije sudjelovanje $u$ društvu.

\section{Zaključak}

Studenti i studentice koje smo obuhvatili ovim istraživanjem medije koriste redovito, ponajviše za informiranje, pa zatim zabavu i komunikaciju s obitelji i prijateljima. Prema medijima su s jedne strane kritični, nemaju povjerenja $u$ medijsko izvještavanje, no $s$ druge strane ih kritičnost i uočavanje nedostataka ne potiče na reagiranje i aktivnost. Sudionici ankete svjesni su važnosti medijske pismenosti; $60 \%$ budućih komunikologa i $39 \%$ budućih teologa i vjeroučitelja smatra se medijski pismenima, a $46 \%$ budućih komunikologa i $36 \%$ budućih teologa smatra da zna kreirati medijsku poruku. Sažetak je to istraživanja koje smo metodom ankete proveli među studentima prve i druge godine Studija komunikologije Hrvatskih studija i Katoličkoga bogoslovnog fakulteta Sveučilišta u Zagrebu.

U istraživanju smo potvrdili svoje polazne pretpostavke da studenti medije koriste za informiranje te da stanje u hrvatskim medijima smatraju lošim. Djelomično smo potvrdili i pretpostavku da studenti Studija komunikologije različito percipiraju važnost medijske pismenosti od studenata Katoličkoga bogoslovnog fakulteta. Naime, studenti obaju studija smatraju da je medijska pismenost važna i da ju je potrebno uključiti u obrazovne programe škola i fakulteta, no studenti ovih dvaju fakulteta imaju različit pristup pojmu medijske pismenosti / medijske kulture. Pristup studenata komunikologije je znanstveno fokusiran i temelji se na znanjima koja su prikupili u tijeku studija, dok je pristup studenata teologije problemski orijentiran i oni smatraju da se medijsko obrazovanje treba povezati s crkvenim naukom o medijima.

Premda je uzorak za istraživanje bio malen, smatramo da su odgovori indikativni i vrijedni za daljnje promišljanje važnosti obrazovanja za medijsku pismenost studenata da bi mogli razumjeti i kritički vrednovati medijske sadržaje i biti aktivni i odgovorni sudionici društvenih zbivanja, jer smatramo da je medijska pismenost važna za društveni angažman studentica i studenata, ali i za razvoj demokracije. Također se nameće i pitanje kako će o medijima na satovima vjeronauka govoriti vjeroučitelji ako sami nisu medijski pismeni, odnosno ako u tijeku studija nisu slušali niti jedan kolegij koji govori o medijima? Stoga smatramo da je potrebna suradnja komunikoloških, odnosno novinarskih studija s teološkim studijem na području medijskoga odgoja, ali također da je potrebno uključiti obrazovanje za medijsku pismenost kao poveznicu između praktičnoga i teoretskog u obrazovanju novinara. 


\section{Suzana Peran* - Anđelka Raguž*** \\ Media literacy: student education and sense of responsibility}

Summary

In this paper, we examine how media literacy, ways of using the media and the evaluation of media content are understood by undergraduate students enrolled at the Department of Communication Sciences - Centre for Croatian Studies and the Catholic Faculty of Theology, University of Zagreb. These students are approached both as media audiences but also as those who will soon be actively creating and/or scientifically evaluating media contents, and those who will be teaching children and young people about media contents. Based on a survey, we have analyzed the extent of the active use of the media and knowledge of the specifics of media function among students of communication sciences within the framework of their awareness of their own professional literacy and their grasp of the importance of media literacy in the context of their professional activities as future teachers of religion.

In conclusion, we analyze the results of the survey and note the possibility of cooperation in the area of media literacy between departments of communication sciences/journalism and departments of theological and other studies. We emphasize the importance of teaching media literacy as part of the education of media professionals and those who will be actively engaged in the teaching of children and young people.

Keywords: Media literacy, undergraduate students, Catholic Faculty of Theology, communications studies, democracy.

(na engl. prev. Margaret Vuko)

\footnotetext{
* Suzana Peran, PhD, Centre for Croatian Studies, Universityof Zagreb; Address: Borongajska cesta 83d, HR-10000 Zagreb; E-mail: suzanavp@gmail.com.

***Anđelka Raguž, MA in journalism, Centre for Croatian Studies, Universityof Zagreb; Address: Borongajska cesta 83d, HR-10000 Zagreb; E-mail: araguz@hrstud.hr.
} 